\title{
Economic Performance of Apple Farms: A Case of Isparta and Karaman Provinces of Turkey
}

\author{
Alamettin Bayav",a,*, Bahri Karlı ${ }^{2, b}$ \\ ${ }^{1}$ Fruit Research Institute, 32500 Ĕgirdir/Isparta, Turkey \\ ${ }^{2}$ Department of Agricultural Economics, Faculty of Agriculture, Isparta University of Applied Sciences, 32005 Isparta, Turkey
} ${ }^{*}$ Corresponding author

\begin{tabular}{|c|c|}
\hline A R T I C L E I N F O & A B S T R A C T \\
\hline $\begin{array}{l}\text { Received : 07/03/2021 } \\
\text { Accepted : 17/03/2021 }\end{array}$ & $\begin{array}{l}\text { Apple cultivation has been done in very large areas around the world. According to FAO, } \\
\text { approximately } 87.2 \text { million tons of apples were produced in the world in } 2019 \text {. Turkey has covered } \\
3.6 \text { million tons of this production and ranked third in the world. In this study, the two major apple } \\
\text { production areas for Turkey, Isparta and Karaman annual operating results of the province apples' } \\
\text { farms, were evaluated. Data acquired by interviewing from } 132 \text { farms selected with the stratified } \\
\text { random sampling method constituted the study's primary material. Classical economic analysis } \\
\text { approaches were used in determining the annual operating results of the farms. The farms' financial } \\
\text { and economic profitability rates were } 8.82 \% \text { and } 7.78 \% \text { in Isparta province, respectively, while } \\
7.25 \% \text { and } 6.15 \% \text { in Karaman province. The research results showed that apple farms did not have } \\
\text { rational capital distribution, their agricultural incomes were low, and their income varied by } \\
\text { province. }\end{array}$ \\
\hline
\end{tabular}

Annual operating results

Economic analysis

Profitability ratio

Turkey

alamettinbayav@hotmail.com

(i) https://orcid.org/0000-0002-8093-2988|b@bahrikarli@isparta.edu.tr

https://orcid.org/0000-0001-9734-1781

(c) (1) () This work is licensed under Creative Commons Attribution 4.0 International License

\section{Introduction}

Regardless of the countries' development level, the agricultural sector plays a role in all countries' economies. Agriculture is a much more important sector, especially in countries with low per capita income. According to TURKSTAT (2021), Turkey's agricultural sector covered approximately $6.42 \%$ of the Gross Domestic Product and $18.15 \%$ of the total employment in 2019.

It was produced about 20 million tons of fruit in Turkey in 2019. Pome fruits constituted $21.5 \%$ of the fruits produced. With 3.6 million tons, apple was the second mostproduced fruit species after grape (FAO, 2021). Apple is a very important fruit in Turkey because it contributes to the country's economy and the region, is related to human nutrition, is used as raw material, and is subject to foreign trade, even if it is a little.

Apple cultivation has been done in almost every region of Turkey. Apple cultivation in Turkey has been mostly done with traditional methods. However, due to policies and programs and extension activities developed in recent years, the establishment of modern orchards with clonal rootstocks has accelerated. The further acceleration of this change is vital for apple because it is a fruit that can appeal to society.

The provinces with the most produced apple in Turkey are Isparta, Karaman, Nigde, Antalya, Denizli, Konya, and Kayseri. Isparta and Karaman are among the provinces with the highest apple production. These two provinces constitute $33.6 \%$ of the total apple production of Turkey. Most of the farms' crop production values that grow apples in Isparta and Karaman province consist of apple production value. In this regard, Isparta and Karaman are possible to say that the important apple regions for Turkey.

As in all economic activities, the farms' primary purpose in agricultural activities is to gain profit to ensure the farms' sustainability. Annual operating results must be known to determine the profitability of farms. It is essential to know the annual operating results in many respects. Knowing the annual operating results is essential for producers to make their production plans in the medium and long term. As in 
many agricultural activities, it is a big problem which there was not recording system in apple farms. Because it is possible to determine the farms' potentials, identify the problems correctly, and develop the right solutions with the recording system. The annual operating results analysis lays out the farms' success and provides information about the farms' strengths and weaknesses.

The main purpose of this research is; In the light of the data obtained, to present the annual operating results of the agricultural farms that produce apples in the provinces of Isparta and Karaman and to develop some solutions by determining the problems encountered.

\section{Material and Method}

\section{Material}

This study's primary material was the data obtained from 132 agricultural farms selected by the stratified random sampling method in Isparta and Karaman provinces. Data referred to the 2017-2018 production season.

\section{Method}

\section{Sampling Procedure}

Isparta and Karaman provinces which covered $33.6 \%$ of Turkey's apple production, were selected as research areas. Eğirdir, Gelendost, Senirkent districts from Isparta province; Central district from the Karaman province were chosen purposefully. The size of the farmland was used as sampling criteria. Neyman Method, one of the stratified random sampling methods, was used in determining the number of agricultural farms to be questionnaires. The number of apple farms to be questionnaire was calculated with the following equation (Yamane, 2001).

$$
\mathrm{n}=\frac{\left(\sum \mathrm{N}_{\mathrm{h}} \mathrm{S}_{\mathrm{h}}\right)^{2}}{\mathrm{~N}^{2} \mathrm{D}^{2}+\sum \mathrm{N}_{\mathrm{h}} \mathrm{S}_{\mathrm{h}}^{2}}
$$

In Equation (1), n: sample size, $\mathrm{N}$ : total number of apple farms, $\mathrm{N}_{\mathrm{h}}$ : number of apple farms in the $\mathrm{h}^{\text {th }}$ group, $\mathrm{S}_{\mathrm{h}}$ : standard deviation of the $\mathrm{h}^{\text {th }}$ group, and $\mathrm{D}$ is the margin of error that is allowed the mean deviation. The margin of error that is allowed for the mean deviation is found with the equation $\mathrm{D}=\mathrm{d} / \mathrm{z}$. In this equation, $\mathrm{d}$ is the allowable margin of error $(\% 5)$, and $\mathrm{z}$ is the table value in the determined confidence level $(\mathrm{z}=1.65)$. The distribution of farms to the strata was made based on the standard deviation with the following equation's help (Yamane, 2001).

$$
\mathrm{n}_{\mathrm{i}}=\frac{\mathrm{N}_{\mathrm{h}} \mathrm{S}_{\mathrm{h}}}{\sum\left(\mathrm{N}_{\mathrm{h}} \mathrm{S}_{\mathrm{h}}\right)} *_{\mathrm{n}}
$$

The distribution of farms by strata and the number of farms surveyed were given in Table 1.

Socio-Economic Analysis Methods

In the farms examined, characteristics such as age and education level of the farmers and the population, labor, and capital structure were evaluated. The labor in the farms was converted into a male labor unit (MLU). The coefficients used in converting the labor to MLU were given in Table 2 (Erkuş and Demirci, 1996).

Used labor and the machinery were calculated in hours. Nitrogen, phosphorus, and potassium content in fertilizers were taken into account.
The capital structures, gross production value, gross income, operating costs, gross profit, net profit, agricultural income, economic and financial profitability of the farms were calculated and compared by provinces and strata. Due to the widespread use of these criteria in the agricultural economics literature, calculation methods were not explained.

\section{Results and Discussion}

The farmers' age, experience apple growing, education level, the population in the farms, labor, and farmland were given in Table 3. While the farmers in the province of Karaman were 54.85 years old, the producers' average age in Isparta was 49.94. Farmers in Isparta province were more experienced than the farmers of Karaman province in terms of apple growing. The education level and farming experience of the farmers were close to each other in both provinces. In the pooled data, it was determined that the producers had an average of 26.74 years of experience and 8.11 years of education level.

In the study carried out by Karamürsel et al. (2004) in Eğirdir, the farmers' average age was found to be 48.26 years, and the average education level was found to be 5.78 years. Compared with the results obtained in our study, although the farmer's average age did not change much in the last 16 years in the province of Isparta, the average duration of education was increased. Gül and Erkan (2005) reported that the average age of apple producers was 51 years and experience was 24 years, with the data they obtained from apple farms in Antalya, Isparta, Karaman, Konya, and Niğde provinces for the 2001 production season. In the study conducted by Bayav (2007) in Isparta, the average farmer age in apple farms was 46.26 years, apple cultivation experience was 22.66 years, and education level was 6.31 years. The results showed that age, experience, and education level increased over time.

Because of the structure of agricultural farms in Turkey entrepreneur, it is in the farm's population. The entrepreneur is defined as the person who produces by bringing together the production factors and taking responsibility for this process's risks. The high level of the entrepreneur's knowledge and education level is considered important for its success (Bayramoğlu, 2014). Many studies showed that the education level of the farmers had an impact on issues such as farms performance, profitability, workforce efficiency, and apply pesticide (Hasdemir, 2011; Kalıpcı et al., 2011; Kılıç and Kıymaz, 2014; Köknaroğlu et al.,2017).

One of the critical factors that must be in agricultural production is labor. The population in the farm also constitutes the labor resource of the farm. In general, the average population per farm was 3.97 people. In all farm groups, the proportion of the male was higher than that of the female. The lowest population per farm was 3.57 people in the first strata in Isparta, and the highest population was the third 5.13 people were found in the strata. The average population for the province of Isparta was 3.95 people. In Karaman province, unlike Isparta, the highest population was in the first strata (4.20 people), the lowest population was in the third strata ( 3.65 people). The average population was 4.00 people per farm. 
Table 1. Sampling volume

\begin{tabular}{|c|c|c|c|c|c|c|}
\hline Strata & Strata Boundaries (ha) & $\mathrm{N}_{\mathrm{h}}$ & $S_{h}$ & Mean & Total Sample & Number of Strata Samples \\
\hline 1 & $0.50-1.50$ & 2,840 & 4.05 & 0.927 & & 38 \\
\hline 2 & $1.51-5.00$ & 2,132 & 8.89 & 2.805 & 132 & 62 \\
\hline 3 & $5.01+$ & 336 & 29.02 & 8.079 & & 32 \\
\hline Total & & & & & & 132 \\
\hline
\end{tabular}

Table 2. Coefficients used in the calculation of the male labor unit

\begin{tabular}{|c|c|c|}
\hline Age (year) & Male & Female \\
\hline $7-14$ & 0.50 & 0.50 \\
\hline $15-49$ & 1.00 & 0.75 \\
\hline $50+$ & 0.75 & 0.50 \\
\hline
\end{tabular}

Table 3. Some characteristics of farms and farmers

\begin{tabular}{|c|c|c|c|c|c|c|c|c|c|}
\hline \multirow{2}{*}{ Province/Strata } & \multicolumn{4}{|c|}{ Isparta } & \multicolumn{4}{|c|}{ Karaman } & \multirow{2}{*}{ Overall Average } \\
\hline & 1 & 2 & 3 & Mean & 1 & 2 & 3 & Mean & \\
\hline Age (year) & 49.22 & 50.93 & 48.27 & 49.94 & 53.73 & 54.70 & 56.00 & 54.85 & 51.87 \\
\hline Experience (year) & 23.91 & 25.69 & 22.67 & 24.61 & 21.27 & 21.30 & 22.88 & 21.81 & 23.51 \\
\hline Education Level (year) & 8.91 & 7.40 & 8.80 & 8.10 & 8.33 & 8.80 & 7.18 & 8.13 & 8.11 \\
\hline Population (person) & 3.57 & 3.74 & 5.13 & 3.95 & 4.20 & 4.15 & 3.65 & 4.00 & 3.97 \\
\hline Labor (MLU) & 2.28 & 2.31 & 3.25 & 2.48 & 2.57 & 2.46 & 2.24 & 2.42 & 2.45 \\
\hline Farmland (ha) & 1.61 & 3.53 & 10.06 & 4.20 & 5.38 & 6.21 & 18.79 & 10.08 & 6.52 \\
\hline Property Land (ha) & 1.19 & 2.98 & 8.79 & 3.56 & 2.46 & 5.20 & 17.33 & 8.37 & 5.46 \\
\hline Property Land (\%) & 74.19 & 84.52 & 87.41 & 84.67 & 45.66 & 83.69 & 92.22 & 83.04 & 83.68 \\
\hline Holding (ha) & 0.42 & 0.55 & 1.27 & 0.64 & 2.92 & 1.01 & 1.46 & 1.71 & 1.06 \\
\hline Holding $(\%)$ & 25.81 & 15.48 & 12.59 & 15.33 & 54.34 & 16.31 & 7.78 & 16.96 & 16.32 \\
\hline Apple Cultivation Land (ha) & 0.92 & 2.66 & 7.95 & 3.15 & 1.10 & 3.33 & 9.09 & 4.57 & 3.71 \\
\hline Apple Cultivation Land (\%) & 77.45 & 89.27 & 90.45 & 88.67 & 44.91 & 63.97 & 48.39 & 45.32 & 68.06 \\
\hline
\end{tabular}

In the study carried out by Karamürsel et al. (2004), the average population of Eğirdir apple farms was found to be 4.00 people. The authors reported that the male population was higher than the female population. Gül and Erkan (2005) found an average population of 4.59 people in their study in apple farms in Antalya, Isparta, Karaman, Konya, and Niğde provinces. Compared to our study, the average population of apple farms did not change much.

The labor amounts of the farms were calculated as MLU. The average MLU was found to be 2.45. In Isparta and Karaman provinces, this value was determined as 2.48 and 2.42 , respectively. Males constituted $61.05 \%$ of the average labor in Isparta and $61.87 \%$ in the Karaman province. In Isparta province, the highest MLU was calculated in the third strata farms with $3.25 \mathrm{MLU}$, in Karaman province with 2.57 MLU and first strata farms.

Technological developments, especially in mechanization, reduce the need for a workforce in many areas. Although the workforce's demand decreases, apple cultivation is a labor-intensive cultivation form, and a workforce is needed at every stage of production. With the development of technology, although the substitution of machinery to the workforce in applications such as weeding and apply pesticides has increased in recent years, the need for labor has reached the highest level, especially in pruning and harvesting applications. At this stage, farms need foreign labor, and it is not easy to substitute machinery for labor. During pruning, applying pesticides, and harvesting, foreign labor demand generally increases. In apple cultivation, the need for workforce decreases in other periods, and the farm labor remains idle.

Average farmland per farm was determined 4.20 hectares in Isparta, 10.08 hectares in Karaman, and 6.52 hectares in general. Property land ratio was high in the farmland in all farm groups. $84.67 \%$ of the farmland in Isparta province and $83.04 \%$ in Karaman province was property land. The average area of apple cultivation was 3.15 hectares in Isparta and 4.57 hectares in Karaman. In Isparta, as the scale of the farm increased, the ratio of apple land increased. In the Karaman, the apple land rate was found to be the highest in the second strata farms.

In the study carried out by Karamürsel et al. (2004) in Eğirdir, the average farmland of apple farms was found to be 1.38 hectares. The average apple area in the farms was found to be 0.80 hectares. The apple orchard ratio in the total area was $68.40 \%$, and almost all of the orchards (98.67\%) were apple orchards. In the study conducted by Bayav (2007) in the province of Isparta, it was reported that the average farmland was 3.05 hectares. When compared with this study, it is possible to say that the average farmland increased in Isparta.

In the study conducted in the province of Karaman, it was determined that the average farmland was 12.31 hectares, and the average apple land was 9.33 hectares (Karaçayır, 2010). The results showed that the average farmland decreased in the province of Karaman

Evaluating the annual operating results of farms will enable them to plan production and be an important data source for future production. In this context, the annual operating results of the farms were evaluated and analysed. Annual operating results of the farms were given in table 4 .

There was an equity-weighted structure in all groups in the farms. In Isparta and Karaman provinces, farm groups with the lowest equity ratio were first strata farms. The farm group with the highest equity ratio was the third strata farms in Isparta and the second strata farms in Karaman province. 
Table 4. Annual activity operating of farms

\begin{tabular}{|c|c|c|c|c|c|c|c|c|c|}
\hline \multirow{2}{*}{ Province/Strata } & \multicolumn{4}{|c|}{ Isparta } & \multicolumn{4}{|c|}{ Karaman } & \multirow{2}{*}{$\begin{array}{l}\text { Overall } \\
\text { Average }\end{array}$} \\
\hline & 1 & 2 & 3 & Mean & 1 & 2 & 3 & Mean & \\
\hline Gross Production Value (TL) & 77,048 & 190,590 & 659,949 & 245,951 & 87,930 & 177,702 & 559,752 & 276,707 & 258,067 \\
\hline Gross Production Value $\left(\mathrm{TL} \mathrm{ha}^{-1}\right)$ & 47,916 & 54,022 & 65,601 & 58,546 & 16,347 & 28,611 & 29,793 & 27,446 & 39,593 \\
\hline Plant Production Value (TL) & 74,579 & 189,024 & 658,642 & 244,175 & 86,543 & 177,702 & 559,752 & 276,307 & 256,833 \\
\hline Plant Production Value (\%) & 96.80 & 99.18 & 99.80 & 99.28 & 98.42 & 100.00 & 100.00 & 99.86 & 99.52 \\
\hline Apple Production Value (TL) & 65,842 & 179,096 & 632,374 & 231, & 50,788 & 145,240 & 476,018 & 226,133 & 229,401 \\
\hline SHP & 88.24 & 94.75 & 96.01 & 94.8 & 58.69 & 81.73 & 85.05 & 81.84 & \\
\hline nimal Produc & 470 & 1,565 & 1,307 & 1,777 & 387 & 0.00 & 0.00 & 400.00 & 1,235 \\
\hline$(\%)$ & 3.20 & 0.82 & 0.20 & & 58 & 0.00 & 0.00 & 0.14 & \\
\hline & 79,331 & 1,980 & 660,166 & 247 & ,302 & 178,113 & 561,813 & 277 & 301 \\
\hline & 49,335 & 416 & 65,623 & 58, & 416 & 28,677 & 29,903 & 27,5 & \\
\hline & 44,642 & 4,169 & 392,879 & 88 & 530 & 116,858 & 302,801 & 159 , & 354 \\
\hline & 27,693 & 247 & 282,777 & 100 , & 38,631 & 81,211 & 226,556 & 116,445 & 106,774 \\
\hline & 62.03 & 72.24 & 71.98 & & 72.17 & 69.50 & 74.82 & 73.06 & \\
\hline c) & 16,949 & 28,922 & 110,102 & 40,701 & 14,899 & 35,647 & 76,245 & 42,934 & 41,580 \\
\hline b) & 37.97 & 27.76 & 28.02 & 28.83 & 27.83 & 30.50 & 25.18 & 26.94 & 28.03 \\
\hline Pese Prot & 49,356 & 115,342 & 377,172 & 145,464 & 49,299 & 96,490 & 333,196 & 160,262 & 151,294 \\
\hline & 30,690 & 32,690 & 37,490 & 34,630 & 9,170 & 15,540 & 11,730 & 15,900 & 23,210 \\
\hline Agricuitural income (1L) & 40,906 & 93,852 & 270,266 & 111,707 & 36,886 & 63,250 & 257,457 & 119,135 & 114,634 \\
\hline & 11,474 & 25,107 & 52,649 & 28,280 & 8,782 & 15,241 & 70,593 & 29,784 & 28,877 \\
\hline 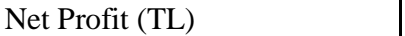 & 5,528 & 31,986 & 104,138 & 37,908 & $-5,887$ & $-14,624$ & 89,918 & 22,074 & 31,670 \\
\hline Net Profit & 3,440 & 9,070 & 10,350 & 9,020 & $-1,090$ & $-2,350$ & 4,790 & 2,190 & 4,860 \\
\hline & 445,210 & 910,185 & $3,038,454$ & $1,175,555$ & 463,034 & $1,332,008$ & $2,897,348$ & $1,593,088$ & $1,340,038$ \\
\hline & 76.33 & 81.52 & 93.12 & 86.08 & 56.94 & 87.77 & 85.67 & 82.81 & 84.52 \\
\hline For & 138,022 & 206,295 & 224,533 & 190,086 & 350,150 & 185,550 & 484,529 & 330,774 & 245,509 \\
\hline & 23.67 & 18.48 & 6.88 & & 43.06 & 12.23 & 14.33 & 17.19 & 15.48 \\
\hline & & & & & & 4.49 & 8.77 & 7.25 & \\
\hline Economic Profitability (\%) & 5.95 & 7.86 & 8.19 & 7.78 & 4.28 & 4.04 & 7.66 & 6.15 & 7.00 \\
\hline
\end{tabular}

SHP: Share of Apple Production Value in Plant Production Value (\%), AIC: Agricultural Income per Capita (TL)

The farms' gross production value was calculated separately as plant production value and animal production value. Almost all of the farms' gross production value consisted of plant production value. The average plant production value per farm was $256,833 \mathrm{TL}$. The average plant production value was $244,175 \mathrm{TL}$ in Isparta and 276,307 TL in Karaman. The farms did in apple cultivation on a large part of the farmland. For this reason, the share of fruit cultivation in the total crop production value was high. In general, the ratio of the apple production value in the plant production value was $89.32 \%$. This rate was $94.82 \%$ in Isparta and $81.84 \%$ in Karaman. As the farmscale increased in Isparta and Karaman provinces, apple production value increased proportionally and in absolute.

Plant production value constituted $99.52 \%$ of the gross production value, and animal production value constituted $0.48 \%$. Gross income value per hectare increased as the farm's size increased in the Isparta and Karaman provinces. In other words, as the farmland increased, the gross production value per unit increased. In Isparta province, the gross production value per hectare was 47,916 TL for the first strata, 54,022 TL for the second strata, and 65,601 TL for the third strata. In the province of Karaman, as the scale of the farm increased, the gross production value per unit area increased. In the province of Karaman, gross production value was $16,347 \mathrm{TL}, 28,611 \mathrm{TL}$, and 29,793 TL per hectare for the first, second, and third strata farms, respectively.

The average gross income per hectare calculated for the farms surveyed was found to be $39,782 \mathrm{TL}$. The gross income per hectare was calculated as 58,886 TL for Isparta and 27,539 TL for Karaman. Based on farm groups, gross income per hectare increased as the farm's scale increased, as in the gross production value. In Isparta, the gross income of the first strata farms was calculated as 49,335 TL per hectare, $54,416 \mathrm{TL}$ for the second strata farms, and $65,623 \mathrm{TL}$ for the third strata farms.

Operating costs are considered as all the costs incurred to obtain gross income for a production period. Operating costs consist of fixed and variable costs. Operating costs are an important measure in comparing resource use. The efficiency of operating costs is of great importance since the main purpose in all production activities with economic goals is profit maximization. If it is not possible to get more yield from the production material, in other words, if the highest yield level has been reached, then the only way to maximize profit is to increase the efficiency of the inputs used.

In the study, the average operating cost per farm was determined as 148,354 TL. $71.97 \%$ of operating costs were variable costs, $28.03 \%$ were fixed costs. Although these rates were close to each other in Isparta and Karaman provinces, $72.17 \%$ of operating costs in Isparta province consisted of variable costs and $27.83 \%$ of fixed costs. In the province of Karaman, these rates were $73.06 \%$ and $26.94 \%$, respectively.

Low or high agricultural income causes a decrease or increase in working capital. The average agricultural income per farm was determined as $114,634 \mathrm{TL}$. The average agricultural income was $111707 \mathrm{TL}$ in Isparta, while it was 119,135 TL in Karaman. Agricultural income per capita was $28,280 \mathrm{TL}$ in Isparta and $29,784 \mathrm{TL}$ in Karaman. As the size of the farm increased, agricultural income per capita increased. 
Gross profit, which is also defined as the income of fixed resources, can be calculated for one production activity and the entire farm. According to the farms' average, the average gross profit per farm was calculated as 151,294 TL. Gross profit per hectare was on average 34,630 TL in Isparta and 15,900 TL in Karaman. In both Isparta and Karaman provinces, gross profit per hectare increased as the farm-scale increased.

The average net profit of farms was 31,670 TL. Net profit was $37908 \mathrm{TL}$ on average in Isparta province and 22,074 TL in Karaman province. Whereas the net profit increased as the farm-scale increased in Isparta province, in Karaman province, the net profit was negative in the first and second group farms and positive in the third group farms.

Farms should cover all subsistence costs of themselves and their family without a reduction in agricultural income and equity. Otherwise, there is a decrease in the capital (İnan, 2016).

The profitability of the farms' production activities can be determined in terms of working capital and the country's economy. While economic profitability explains the profitability of the farm's total capital and its contribution to the economy, financial profitability explains equity capital's profitability (Bayramoğlu, 2014).

Financial profitability in the farms was found to be $8.08 \%$ on average. Financial profitability explains whether the equity participating in production receives sufficient income from production. Whether this value is positive or negative is important in terms of ensuring the continuity of farms. Negative financial profitability will cause a decrease in equity capital in the long run and pose a danger to farms' sustainability (Bayramoğlu, 2014). On a regional basis, the average financial profitability rate was calculated for the Isparta province's farms as $8.82 \%$ and Karaman province's farms as $7.25 \%$. According to farm scale, the highest financial profitability rate in Isparta was obtained in the second strata farms with $9.38 \%$ and the lowest in the first strata farms with $7.59 \%$. In Karaman province, a ratio of $6.99 \%$ in the first group farms, $4.49 \%$ in the second group farms, and $8.77 \%$ in the third group farms stood out.

The average economic profitability of the farms was calculated as $7.00 \%$. While the average economic profitability in Isparta province farms was $7.78 \%$, this rate was $6.15 \%$ in Karaman province. Economic profitability ratios differentiated according to farm size. In Isparta and Karaman provinces, the highest economic profitability rates were obtained in the third group farms.

The interpretation of only the given financial profitability and economic profitability rates is insufficient. The general opinion is that banks should take a value close to the nominal interest rate applied to evaluate profitability rates. When evaluated from this point of view, it can be said that the calculated profitability rates remained at low levels, especially in the province of Karaman when compared with the nominal interest rate of $9.00 \%$ (TCZB, 2020). The profitability rates should be close to the nominal interest rate for the sustainability of the farms.

\section{Conclusion}

Turkey is one of the most important countries in the world apple production. The fact that it appeals to people's income level and taste and that it can be cultivated in almost every geography makes apple one step ahead among other fruits. Although apples are produced in every region in Turkey, Isparta and Karaman province are noteworthy in production volume and modern producing techniques. Isparta and Karaman provinces cover about 1/3 of Turkey's apple production.

One of the factors affecting farm success is the distribution of capital within itself. The farms' capital distribution was analyzed, and it was determined that almost all farms do not have the desired capital distribution. According to the farms' average, the average capital was more than 1.5 million TL, and the farms with such high active capital could not show the desired financial performance. The lack of a record-keeping system, a general problem of Turkey's agricultural farm, is a big problem in the apple farm too. Because determining the farm potentials, determining the problems correctly, and developing the right solutions to these problems is possible by record-keeping. The results revealed the necessity of training farmers in capital management and record keeping. Besides, the obligation to keep records for farms in agricultural subsidies will contribute to the formation of record-keeping habits in farms.

In the plant production value, although the apple production value was higher in Isparta compared to Karaman, it was more than $50 \%$ in both provinces. Gross profit, agricultural income, and net profit were higher in Isparta province apple farms than in Karaman. Especially in the province of Karaman, it was observed that the farms' sustainability in the first and second strata was difficult. The sustainability of these farms needs to be supported with technical knowledge and interest-free or low-interest loans. Agricultural income was at very low levels, especially in small-scale farms. Developing policies to increase agricultural income is one of the most important issues in farms' sustainability. Financial and economic profitability rates were also below the nominal interest rates applied by banks. Necessary measures should be taken in capital management and to increase production value. Policies for record-keeping and balanced capital management should be developed.

\section{Acknowledgments}

This paper was derived from the corresponding author's doctoral dissertation.

\section{References}

Bayav A. 2007. Adoption Levels of the Innovations and Research Findings, and Impact Assessments in the Apple Growing Enterprises in İsparta Province. MSc Thesis, Institute of Natural and Applied Sciences, Adnan Menderes University, Aydın, Turkey. Available from: http://adudspace.adu.edu. tr:8080/xmlui/bitstream/handle/11607/227/te_alamettin_bay av_ozet_en.pdf?sequence $=1 \&$ isAllowed $=\mathrm{y}$ [Accessed: 10 February 2021].

Bayramoğlu Z. 2014. The Effects of Anti-Risk Behaviours of Producers Performing Cherry Cultivation on Processing Income: Akşehir District Example. Tarım ve Orman Bakanlığı, Tarımsal Ekonomi ve Politika Geliştirme Enstitüsü Yayınları. ISBN 978-605-46-72-69-1.

Erkuş A, Demirci R. 1996. Tarımsal İşletmecilik ve Planlama. Ankara Üniversitesi Ziraat Fakültesi Yayınları. 
FAO, 2021. Food and Agriculture Organization of the United Nations. FAOSTAT. Available from: http://www.fao.org/faostat/en/\#data/QC [Accessed 15 February 2021]

Gül M, Erkan O. 2005. Economic Analysis of Apple Farming in the Trans Taurus Mountains Region. Çukurova University, Journal of the Faculty of Agriculture, 20: 87-96.

Hasdemir M. 2011. The Analysis of the Factors That Affect the Adoption of the Cherry Growing in Good Agricultural Practices. PhD Dissertation. Institute of Natural and Applied Sciences, Ankara University, Ankara, Turkey.

İnan İH. 2016. Tarım Ekonomisi ve İşletmeciliği. İdeal Kültür ve Yayınc1lık. ISBN 978-605-5729-67-7.

Kalıpc1 E, Özdemir C, Öztaş H. 2011. Investigation of Environmental Awareness and Education and Information Levels of Farmers Related with Pesticide Usage. Journal of TUBAV Science, 4: 179-187.

Karaçayır HF. 2010. Pesticide Usage Extension Approaches in Apple Production Enterprises; The Case Study of Karaman Province. MSc Thesis, Institute of Natural and Applied Sciences, Selçuk University, Konya, Turkey.
Karamürsel D, Öztürk FP, Öztürk G, Kaymak S, Eren İ, Akgül H. 2004. Eğirdir Yöresi Elma Yetiştiriciliğinin Durumu ve Sorunlarının Belirlenmesi ile Ekonomik Yönden Değerlendirilmesi. Türkiye VI. Tarım Ekonomisi Kongresi, Tokat, Turkey, 16-18 September, pp: 225-231.

Kılıç Y, Kıymaz T. 2014. The Relationship between Education and Labor Productivity in Agriculture: Regional Differences. Turkish Journal of Agricultural Economics, 20: 53-64.

Köknaroğlu H, Demircan V, Y1lmaz H, Dernek Z. 2017. Effect of education level on performance and profitability of beef cattle production. Isparta University of Applied Science, Journal of the Faculty of Agriculture, 12: 75-84.

TURKSTAT, 2021. Turkish Statistical Institute. Available from: https://tuikweb.tuik.gov.tr/UstMenu.do?metod=temelist [Accessed 15 February 2021]

Yamane T. 2001. Temel Örnekleme Yöntemleri. Literatür Yayınc1lı. ISBN 975-8431-34-X.

TCZB, 2020. Ziraat Bank. Available from: https://www. ziraatbank.com.tr/tr/fiyatlar-ve-oranlar [Accessed 15 July 2020] 